\title{
Modern communication technologies in education: book trailer
}

\section{Tecnologias de comunicação modernas na educação: trailer de livro}

\section{Tecnologías de comunicación modernas en la educación: tráiler de libro}

\author{
Nadezhda Ilinichna Nikonova1 ${ }^{1}$, Svetlana Yrievna Zalutskaya ${ }^{1}$ iD \\ ${ }^{1}$ M.K. Ammosov North-Eastern Federal University, Yakutsk, Russian. \\ Corresponding author: \\ Nadezhda Ilinichna Nikonova \\ Email: nikon_nad@mail.ru \\ How to cite: Nikonova, N. I., \& Zalutskaya, S. T. (2021). Modern communication technologies in education: book \\ trailer. Revista Tempos e Espaços em Educação, 14(33), e15256. http://dx.doi.org/10.20952/revtee.v14i33.15256
}

\begin{abstract}
The article deals with the problem of encouraging the reading activity of pupils through modern communication technologies. As a tool to attract the attention of teenagers to reading, the authors turn to a multimedia advertising product, namely, a book trailer. The relevance of its application in teaching is determined by the context of the time, digitalization and virtualization of education, social trends, and features of the perception of information by today's reader and viewer. The article substantiates the fruitfulness of using the book trailer in the educational environment by the results of content analysis of scientific works of Russian and foreign researchers, practitioners, and practical testing in the educational process. As an experimental research method, the authors used a survey of pupils of the sixth and seventh grades of the Second Malzhagar Middle School named after M.E. Vasilyeva of the "Khangalassky Ulus" municipal district, as well as rural teachers of the literature of the Republic of Sakha (Yakutia) of the Far Eastern Region of the Russian Federation. The survey involved 47 pupils and 31 respondents from among regional teachers of the Russian language and literature. The problem of reading was considered in terms of uncovering the creative potential of pupils of the sixth and seventh grades who were studying under the elective program "Book Trailer: Create, Watch, and Read". The research results aimed at determining the book trailer as an effective means of developing pupils' interest in reading, implementing their creative abilities in the course of developing a product for the information and educational environment of the region. The authors conclude that the creation of book trailers is one of the most relevant motivators for pupils in their cognitive activity as it combines work with a book and mastering modern communication technologies, increases interest in learning and the level of motivation to read.

Keywords: Communication technologies. Training. Digitalization of the educational environment. Multimedia advertising product. Book trailer.
\end{abstract}




\section{RESUMO}

$\mathrm{O}$ artigo trata do problema do incentivo à atividade de leitura dos alunos por meio das modernas tecnologias de comunicação. Como ferramenta para atrair a atenção dos adolescentes para a leitura, os autores recorrem a um produto publicitário multimédia, nomeadamente, um trailer de livro. A relevância de sua aplicação no ensino é determinada pelo contexto do tempo, digitalização e virtualização da educação, tendências sociais e características da percepção da informação pelo leitor e telespectador de hoje. $\mathrm{O}$ artigo comprova a fecundidade do uso do trailer do livro no ambiente educacional pelos resultados da análise de conteúdo de trabalhos científicos de pesquisadores russos e estrangeiros, profissionais e testes práticos no processo educacional. Como método de pesquisa experimental, os autores utilizaram uma pesquisa com alunos da sexta e sétimas séries do Segundo Ensino Fundamental Malzhagar em homenagem a ME Vasilyeva do município de "Khangalassky Ulus", bem como professores rurais da literatura da República do Sakha (Yakutia) da região do Extremo Oriente da Federação Russa. A pesquisa envolveu 47 alunos e 31 entrevistados entre professores regionais de língua e literatura russa. O problema da leitura foi considerado em termos de descobrir o potencial criativo dos alunos da sexta e sétimas séries que estavam estudando no programa eletivo "Trailer de livro: criar, assistir e ler". Os resultados da pesquisa visaram determinar o trailer do livro como um meio eficaz de desenvolver o interesse dos alunos pela leitura, implementando suas habilidades criativas no curso de desenvolvimento de um produto para o ambiente informativo e educacional da região. Os autores concluem que a criação de trailers de livros é um dos motivadores mais relevantes para os alunos na sua atividade cognitiva, pois alia o trabalho ao livro e o domínio das modernas tecnologias de comunicação, aumenta o interesse pela aprendizagem e o nível de motivação para a leitura.

Palavras-chave: Tecnologias de comunicação. Treinamento. Digitalização do ambiente educacional. Produto de publicidade multimídia. Trailer de livro.

\section{RESUMEN}

El artículo aborda el problema de fomentar la actividad lectora de los alumnos a través de las modernas tecnologías de la comunicación. Como herramienta para atraer la atención de los adolescentes hacia la lectura, los autores recurren a un producto publicitario multimedia, a saber, un avance de libro. La relevancia de su aplicación en la docencia está determinada por el contexto del tiempo, la digitalización y virtualización de la educación, las tendencias sociales y las características de la percepción de la información por parte del lector y espectador de hoy. El artículo corrobora la utilidad de utilizar el avance del libro en el entorno educativo mediante los resultados del análisis de contenido de trabajos científicos de investigadores y profesionales rusos y extranjeros, y las pruebas prácticas en el proceso educativo. Como método de investigación experimental, los autores utilizaron una encuesta a alumnos de sexto y séptimo grados de la segunda escuela secundaria Malzhagar, que lleva el nombre de ME Vasilyeva del distrito municipal de "Khangalassky Ulus", así como a profesores rurales de literatura de la República de Sakha (Yakutia) de la región del Lejano Oriente de la Federación de Rusia. En la encuesta participaron 47 alumnos y 31 encuestados de entre los profesores regionales de lengua y literatura rusas. El problema de la lectura se consideró en términos de descubrir el potencial creativo de los alumnos de sexto y séptimo grados que cursaban el programa electivo "Trailer de libros: crea, mira y lee". Los resultados de la investigación tuvieron como objetivo determinar el avance del libro como un medio eficaz para desarrollar el interés de los alumnos por la lectura, implementando sus habilidades creativas en el transcurso del desarrollo de un producto para el entorno informativo y educativo de la región. Los autores concluyen que la creación de avances de libros es uno de los motivadores más relevantes para los alumnos en su actividad cognitiva, ya que combina el trabajo con un libro y el dominio de las tecnologías de la comunicación modernas, aumenta el interés por el aprendizaje y el nivel de motivación para leer. 
Palabras clave: Tecnologías de la comunicación. Formación. Digitalización del entorno educativo. Producto publicitario multimedia. Tráiler del libro.

\section{INTRODUCTION}

In the context of digitalization of the modern world, visualization of the art, increased dependence of a human on the virtual environment, the value of information tools that help people quickly and effectively navigate the digital cultural reality, enhances. The latest information and communication technologies are rapidly changing the world and a human as the main consumer of information, the reader, and the creator of the information product. Therefore, the high reading activity of the young generation, fully adapted to the digital space, has become today the most important criterion for the success of society in general. The innovations implemented in the education and culture in all countries of the world show that young people have changed the ways of interacting with the book as a source of information, a form of leisure, and a tool for obtaining an education. The book ceases to function in the usual format, lives its own special life in the digital environment. Establishing communication between the book and the young reader requires technology adequate to the modern information environment, taking into account the age-specific perception of the consumer. Such technologies are successfully used, for example, in advertising.

A book trailer, as a commercial for a book, has become one of the most effective advertising technologies that attract the consumer's attention. The practical use of book trailers has become widespread not only in book advertising but also in education since the beginning of the $21^{\text {st }}$ century. This is due to the ability of a visual multimedia advertising product to influence the consciousness of the target audience, encourage it to act, and form the reading culture of a man of today. Book trailer as "a socio-cultural phenomenon has taken its strong place in the range of methodological tools, whose purpose is to motivate the learner's personality to dynamic cognitive activity" (Zalutskaya \& Nikonova, 2020, p. 116).

Content analysis of scientific pedagogical literature (Volkova, 2015; Yakina, 2014; Shcherbinina, 2016; Mokhun, 2016; Morozov \& Lisovskaya, 2014) has revealed that the book trailer, which is used in the educational process as a means of learning, is defined by researchers as a "tool of book advertisement", and "visual essay" (Volkova, 2015, p. 209), "the genre of online communication, a short video, telling in any form about the book, visualizing the most striking and recognizable points of its contents" (Yakina, 2014, p. 42), "the announcement on the book in the form of a short video teaser, which includes the most striking points of the book, and visualizes its content in one form or another " (Kopylova, 2012), "the noticeable attribute of the publishing industry, and a significant phenomenon of book culture" (Shcherbinina, 2016, p. 18), "innovative method that increases the reader's interest" (Mokhun, 2016, p. 77), "a short video based on the book; video abstract of the book; the video short story, teaser, which includes the brightest and most recognizable points of the book, visualizes its contents; a short video telling about the book in any form " (Book trailer: a modern way to promote books in the library: guidelines, 2014, pp. 4-5). The most accurate definition of the book trailer in the context of the problem under consideration is the following: book trailer is "a special type of visual interpretation of a literary text (both classic and modern) through multimedia aimed at attracting the reader's attention" (Kolova \& Vrublevsky, 2019, p. 463).

Vasiukovich A., the author of the book debuts club's project "Your First Book", identifies the following main tasks of the trailer:

- "to draw attention to the book;

- create an audience of readers;

- create a personal brand of the writer" (Kak sdelat' buktrejler, 2020).

When using in the educational process a type of cognitive activity of pupils, such as a book trailer, the teacher not only expands the audience's reading horizons but also increases the level of 
reading quality, helps to comprehend the meaning of a work of fiction, enter into a dialogue with the author. Scientists emphasize that the book trailer will become an effective methodological tool for increasing learners' interest in reading, provided that the informational, communicative, aesthetic, and cultural and educational functions of a multimedia product are taken into account, while not turning "visual embodiment" into "textual disembodiment " (Shcherbinina, 2016, p. 19).

In recent years, foreign scientific publications have updated the potential of digital storytelling in the educational process. Thus, researchers analyze models of Bulgarian digital book trailers and the possibilities of their use for educational purposes (Dimova et al., 2018), identify the structural and general characteristics of book trailers, compare book trailers with movie trailers (Brössel, 2018), summarize the results of content analysis of book trailers (Basaraba, 2016). The creation of book trailers is considered as a tool for the acquisition and development of basic competencies, creativity, and multimodal literacy of learners. The main attention is focused on the use of book trailers as a way to develop reading skills and an opportunity to teach students to enjoy literary reading (Ibarra-Rius \& Ballester-Roca, 2018), as well as the means of developing literary and technological skills of trainee teachers (Aliagas-Marín \& Margallo, 2016). Foreign researchers also determine the relevance of the book trailer as a digital tool that promotes the development of reading and the acquisition of literary competence by future teachers (Romero et al., 2019). The authors emphasize that the creation of trailers for books stimulates the study of classical literature (Baize, 2019). Thus, digital storytelling in foreign scientific literature is a pedagogically valuable approach to the development of pupils and future teachers. The advantages of book trailers are their brevity, brightness, and informative content.

This tool forms the research skills of learners, allows them to show and develop creative abilities, teaches them to critically perceive and independently create information, and opens up new horizons for promoting books in the information space. A book trailer is characterized by specialists as a modern and attractive way to invite the attention of contemporary schoolchildren to read.

\section{METHODOLOGY}

To identify pupils' reading activity and their attitude to the book trailer, a special survey was conducted on September $7^{\text {th }}, 2019$. The survey was attended by 47 respondents, the pupils of the sixth and seventh grades of the Second Malzhagar Middle School named after M.E. Vasilyeva of the "Khangalassky Ulus" municipal district of the Republic of Sakha (Yakutia).

The anonymous survey consisted of the following questions:

1. Do you like reading?

2. Why don't you like reading?

3. How often do you read extracurricular literary works?

4. How do you choose books?

5. Do you know what a book trailer is? Do you watch them?

To the question "Do you like to read?", 38\% of pupils gave a positive answer, $29.7 \%$ were not sure, while $31.9 \%$ of respondents answered "no". As is seen, the ratio of those who like and those who do not like reading is almost equal. Respondents who have constant need to read slightly dominate. However, the sum of negative responses and responses of pupils who are in doubt indicates the fact of unstable interest of adolescents in reading.

Answers to the question "Why don't you like reading?" are presented in table 1. 
Table 1. Answers to the question "Why don't you like reading?» (\%).

\begin{tabular}{ll}
\hline The response options & Percentage \\
\hline Requires a lot of time & $17 \%$ \\
No spare time since all the time is spent on studying & $20 \%$ \\
No spare time, because there are more interesting things to do & $34 \%$ \\
It's boring & $27 \%$ \\
\hline
\end{tabular}

As can be seen from Table 1, the majority of respondents choose other types of leisure activities (34\%), considering reading a boring activity (27\%). These indicators should activate teachers in their search for motivators for reading.

The respondents' answers to the third question allow concluding that the majority of schoolchildren read literary works recommended by the curriculum, which are necessary for education. The regularity of reading literary works from the category of extracurricular literature was as follows: $10.6 \%$ of schoolchildren read extracurricular literary works several times a week, $21.2 \%$ - several times a month, $27.6 \%$ - several times a year, and $40.4 \%$ did not read literary works that were not included in the literature curriculum.

Answers to the question "How do you choose books?" are presented in table 2.

Table 2. Answers to the question "How do you choose books?" (\%).

\begin{tabular}{ll}
\hline The response options & Percentage \\
\hline I find recommendations on the Internet (Instagram, Facebook, Vkontakte, & $36 \%$ \\
YouTube) & $31,9 \%$ \\
I read the random book I see & $21 \%$ \\
I read books offered by teachers/librarians & $17 \%$ \\
I read books offered by friends & $8 \%$ \\
I read books offered by parents & $8 \%$ \\
\hline
\end{tabular}

The obtained results indicate that pupils need help with orientation in the book space: $31.9 \%$ of respondents chose a book by random sampling, while $36 \%$ of pupils looked for recommendations on the Internet. Such recommendations are subjective and may not accurately convey the meaning and atmosphere of a literary work. There is a need to teach teenagers the rules of self-selection of books, as well as to analyze incoming information.

The answers to the question whether respondents know what a book trailer is, whether they watch it, were as follows: "I know, and I watch them "-39.1\%, "I know, I don't watch" - 15.2\%, and "I have no idea" - $45.7 \%$. The questionnaire has shown that most pupils know about the book trailers, but not everyone is watching them. In general, respondents prefer amateur book trailers displayed on YouTube video hosting. The interest in amateur video products is justified by the popularity of bloggers advertising books. These people represent an extraordinary, creative, popular part of society. Unlike library and publishing book trailers, amateur book advertising is created by people of different professions and ages. They tell personal stories about their favorite literary works to get a response, feedback from other readers, enter into an equal dialogue with them, and enrich their reading experience. This approach to the promotion of reading attracts modern visual learners.

To justify the need for targeted pedagogical work to enhance the reading activity of schoolchildren, a survey was conducted among teachers of the Russian language and literature in rural schools of the Republic of Sakha (Yakutia). The survey was conducted on September 7-9, 2019, involved 31 respondents selected by random sampling. The average experience in the teaching of the respondents was 15 years. The survey included the following questions:

1. Is the problem of reading passivity of schoolchildren relevant today? What do you think? 
2. Do you use tools to increase the reading activity of pupils in your teaching practice?

3. Do you know what a book trailer is? Do you use it in your practice?

According to the results of the survey, it became clear that $93.5 \%$ of teachers considered the problem of reading passivity of schoolchildren to be relevant. Absolutely all respondents (100\%) believed that the level of reading activity should be increased.

The survey has shown that $90.3 \%$ of rural teachers in the region used various means to increase pupils' reading activity in their practice, such as extracurricular reading lessons, a list of recommended literary works, informing about new literature, quizzes, games, and competitions, keeping a reader's diary, visiting libraries, conducting tests on previously read books, holding reading conferences, and literary evenings. In the context of the study, methods of working in literature lessons, such as fast reading, advertising of e-books, filmed works of art, including in the book trailers, are of interest; as well as a linguistic fairy tale; reading with notes; drawing up a reference scheme; drawing up a comparative table; reading hours; five minutes breaks for advertising, etc.

The question "Do you know what a book trailer is? Do you use it in your practice?" was answered by the respondents as follows: $29 \%$ of teachers used book trailers as a means of developing reader interest; $58.1 \%$ knew about the book trailer but for various reasons (no experience, low level of knowledge of information and communication technologies, lack of understanding of effectiveness as a means of teaching, and others) did not use it in practice; $12.9 \%$ of respondents did not know what a book trailer was. At that, teachers agreed that the use of book trailers in the educational process was implemented as 1) "viewing and discussing ready-made videos; 2 ) independent creation and presentation of their "verbal-visual products" (Shcherbinina, 2016, p. 18).

The data obtained indicate that the responses of pupils and teachers of rural schools in the region are correlated. On the one hand, learners are not interested in constant reading, especially of extracurricular literary works. They find more interesting activities (socializing with friends, watching movies and videos), having no time for leisure reading. On the other hand, Yakut teenagers focus their attention on books advertised on the Internet, which indicates a fairly high level of mastering digital communication. At the same time, rural teachers of the Russian language and literature are looking for ways, methods, and means to expand the readers' horizons, improve the educational and cultural level of pupils. However, the book trailer as a methodological tool remains unexplored by rural teachers, and requires testing, mastering for active inclusion in the system of methods used in regional pedagogical practice for the development of pupils' reading culture. Thus, the use of book trailers in the literary education of teenagers in Yakutia is a relevant and necessary means of increasing the readers' interest in learners, while the technology of organizing communication in the "author - book - reader - other readers" system is adequate to modern realities.

\section{RESULTS}

The virtualization and digitalization processes of modern education have become a condition for the emergence and distribution of multimedia educational products. These include the book trailer which is an effective tool for supporting and developing reading. In the course of studying the issue of using the book trailer in teaching schoolchildren, the program of the elective educational course "Book Trailer: Create, Watch, and Read" for pupils of the sixth and seventh grades was tested at the Second Malzhagar Middle School named after M.E. Vasilyeva in Yakutia. At that, 47 pupils were trained under the program from September 7 to October 7, 2019.

The purpose of the program was to form and develop pupils' need to read literary works through the creation of book trailers. 
Figure 1. Scheme for creating a book trailer.

\begin{tabular}{|l|l|}
\hline Book selection & \begin{tabular}{|l|}
\hline Text writing \\
\hline Script writing
\end{tabular} \\
\hline $\begin{array}{l}\text { Selection and } \\
\text { recording of } \\
\text { video and } \\
\text { audio materials }\end{array}$ \\
\hline $\begin{array}{l}\text { Selecting video } \\
\text { and audio } \\
\text { devices }\end{array}$ \\
\hline $\begin{array}{l}\text { Book trailer } \\
\text { montage }\end{array}$ \\
\hline $\begin{array}{l}\text { Book trailer } \\
\text { broadcasting }\end{array}$ \\
\hline
\end{tabular}

The program of the "Book Trailer: Create, Watch, and Read" course was designed for 18 hours to organize extracurricular activities of pupils in the sixth and seventh grades aimed at implementing the requirements of the Federal State Educational Standard of Basic General Education (2010) in terms of the formation of personal, meta subject, and subject results of mastering the basic educational program. In the course of mastering the program, pupils acquired the skills of processing and searching for information using information and communication technologies; mastered the technologies of working with various types of information forms (text, sound, image, digital data); developed the skills of working with software applications, such as "Film Studio. Windows Movie Maker", and "Vegas Pro 17", as well as the multimodal literacy (TaberneroSala, 2016).

Table 3. Thematic planning of the elective educational course.

"Book Trailer: Create, Watch, and Read"

\begin{tabular}{llll}
\hline No. & Training subject & $\begin{array}{l}\text { Number } \\
\text { of hours }\end{array}$ & The content of the lesson \\
\hline 1. & What is a book trailer? & 1 & $\begin{array}{l}\text { Safety instructions. Introduction. The concept of a book trailer. The history } \\
\text { of the book trailer. } \\
\text { Classification of book trailers. }\end{array}$ \\
\hline 2. & $\begin{array}{l}\text { Book trailer as a result } \\
\text { of meaningful reading }\end{array}$ & $\begin{array}{l}\text { Working with the literary text. The main idea of the literary work. An idea. } \\
\text { The main characters. The author's position. Reading literary works. }\end{array}$ \\
\hline 3. & $\begin{array}{l}\text { What is read in the } \\
\text { world? }\end{array}$ & 1 & $\begin{array}{l}\text { Familiarizing with fiction novelties. Recommendation of literary works. } \\
\text { Viewing book trailers. }\end{array}$ \\
\hline 4. & $\begin{array}{l}\text { Choosing a book for } \\
\text { advertising }\end{array}$ & 1 & $\begin{array}{l}\text { Choosing a literary book by a group of pupils to create a book trailer. } \\
\text { Developing the book abstract and advertising slogan. }\end{array}$ \\
\hline 5. & $\begin{array}{l}\text { Creating a script of the } \\
\text { book trailer }\end{array}$ & 1 & $\begin{array}{l}\text { Developing a work plan. Creating a script for the book trailer. Choosing the } \\
\text { type and style of a book trailer. }\end{array}$ \\
\hline 6. & How does it work? & 2 & $\begin{array}{l}\text { Familiarizing with the camera, video camera, and voice recorder. } \\
\text { Familiarizing with software applications "Film Studio. Windows Movie } \\
\text { Maker ", and "Vegas Pro 17". }\end{array}$ \\
\hline
\end{tabular}




\begin{tabular}{llll}
\hline 8. $\begin{array}{l}\text { Editing and creating a } \\
\text { book trailer }\end{array}$ & $\begin{array}{l}\text { Creating video files using software applications "Film Studio. Windows } \\
\text { Movie Maker", and "Vegas Pro 17". Preparing clips. Editing the video. } \\
\text { Applying video effects. Adding transitions. Inserting captions and text. } \\
\text { Working with audio materials. Saving a video. }\end{array}$ \\
\hline $\begin{array}{l}\text { Coming to the finish } 1 \\
\text { line }\end{array}$ & $\begin{array}{l}\text { Viewing the created book trailer. Making adjustments. Making changes. } \\
\text { libraries }\end{array}$ & to 2 & $\begin{array}{l}\text { Public screening of the book trailer. Ratings of viewers and experts. } \\
\text { Reflection. }\end{array}$ \\
\hline
\end{tabular}

The architecture of the training course used a certain sequence of creating book trailers. It was taken into account that the development of a multimedia product was a multimedia technology (Bulanova-Toporkova, 2006, p. 160) with a mandatory reliance on the analysis and interpretation of a literary work.

Below are the stages that pupils go through when learning how to create a book trailer.

1. Monitoring. The author should follow all the latest trends in the advertising industry, international and local festivals, and book trailer competitions, as well as do not forget to constantly review the videos to identify their main possible disadvantages and advantages.

2. Selecting a book. The book chosen for advertising should be interesting for the target audience and have moral potential.

3. Creating a script. The optimal duration of the video should be observed. A video should not last longer than three minutes, because the viewer's attention decreases quite quickly. Next, the author should write a structured advertising text. The plot of the video should have an inciting incident, climactic scene, and falling action. However, one should be careful here - not to convey the whole content of the book, otherwise, the reader will lose interest in reading it. A prerequisite for the success of the book trailer is the intrigue that must be laid in the plot. In the course of writing a script, it is recommended to immediately think through the visual presentation and, if possible, make a storyboard of the video.

4. Selecting material for the video series. Several sources can be used to get video material: actual shooting; using video from existing databases without copyright infringement; transforming the book's illustrative material into animation. The author should be able to choose the format and quality parameters of the video, which depend on the capabilities of the technique and the way the product is placed.

5. Sound recording. The author of the book trailer can record the voice, replicas of characters, and process them in specialized programs. It is possible also to make a musical soundtrack or combine voice and music during the editing process.

6. Editing. To create a full-fledged promo video of the book, it is necessary to put together all the video and audio materials. Editing allows gluing and cutting pieces of video and audio, change their size and position, color, saturation, apply effects, etc. The author of the book trailer must indicate the authorship of the creators of all elements of the video in the credits.

7. Presenting and disseminating. Presenting at the school, library with subsequent dissemination on the Internet and social networks. Most users have access to the video hosting services, such as YouTube, Instagram, Facebook, Vkontakte, Twitter, and other popular social networks which are an additional tool for disseminating the book trailer.

The work on the creation of book trailers aims teenagers at a deep and meaningful reading of literary works, thorough study of the biography of the writer, and the historical time of the creation of the literary text. When visualizing a book, it is necessary to understand exactly what feelings are experienced by the characters of the work, and what feelings need to be evoked in the audience as future potential readers. The main task of the teacher when using book trailer in training is creating a situation of success, opportunities for self-expression, and self-actualization of learners through reading literary work and producing a creative product that can only be done by a 
well-trained person.

As an example, a fragment of the second lesson of a proven training program is presented below. The topic of the lesson was: "Book trailer as a result of meaningful reading". The objective of the lesson was to develop the skills of analyzing a literary text. Learners actualized theoretical concepts, such as the main thought of the literary work, basic idea, main characters, and the author's attitude. At the first stage of work, pupils together with the teacher read the stories "Paper Victory" by L.E. Ulitskaya (2012) and "Geranium in the Snow" by V.P. Astafyev (2008). The pupils used the technique of reading with pauses so that the perception of the literary work was the most complete, integrated, and correct. For the same purpose, the technique of "difficult" and "easy" questions was used.

Table 4. "Easy" and "difficult" questions.

\begin{tabular}{|c|c|}
\hline "Paper Victory" by L.E. Ulitskaya & "Geranium in the Snow" by V.P. Astafyev \\
\hline "Easy" questions: & "Easy" questions: \\
\hline 1. What time of year did the action take place? & 1. Where did the event take place? \\
\hline 2. Who was the initiator of the holiday? & 2. What difficulties did the geranium encounter? \\
\hline \multirow{2}{*}{ 3. What book always laid at the side of the main character? } & Describe them \\
\hline & 3. In which pot did the geranium grow? \\
\hline "Difficult" q & "Difficult" qu \\
\hline 1. What made Genya "an & 1. What did $t$ \\
\hline 2. Why did Genya not want to invite anyone to & 2. Why could the geranium not grow on the ground? \\
\hline 3. What made the boy happy? & 3. Why did the author call the flower "little geranium"? \\
\hline
\end{tabular}

After reading and comprehending the literary works, pupils analyzed them. At this stage, an image-based analysis of "Paper Victory" and a problem-based analysis of "Geraniums in the Snow" were quite fruitful. During the analysis, pupils identified the main concept, the basic idea of the literary work, as well as the author's attitude.

At the final stage of the analysis, the pupils made cinquains to selected literary work, which served as a means of creative expression of the reader's impressions of teenagers.

Table 5. Examples of pupils' cinquains.

\begin{tabular}{ll}
\hline "Paper Victory" by L.E. Ulitskaya & "Geranium in the Snow" by V.P. Astafyev \\
\hline Genia... & Geranium... \\
Unhappy, strong. & Red, alive. \\
He gets sick, creates, wins. & It breaks, grows, gives up. \\
He was able to defeat himself. & Geranium flower really wanted to live! \\
He wins! & It tried... \\
\hline Mother... & Peasant man. \\
Strong, talented! & Drunk, scary. \\
Plays, helps, loves! & Drinks, breaks, crushes. \\
Mother knows what to do. & He ruined everyone's life! \\
Victory! & He hasn't changed. \\
\hline
\end{tabular}

A detailed analysis of the stories of Ulitskaya and Astafiev allowed not only improving the skills of interpreting the literary text but also mastering the basic skills of creating a script for a book trailer based on these literary works.

In the course of mastering the program of the elective course "Book Trailer: Create, Watch, and Read", pupils of the sixth and seventh grades independently created eight book trailers. As an example, consider four of them, which are the most successful. For advertising, the authors have chosen the following literary works: the story of V.G. Gubarev "The Kingdom of Crooked Mirrors", the story of E. Verkin "Cloud Regiment", a series of novels by J.K. Rowling about Harry Potter, and the story of A. de Saint-Exupery "The Little Prince". 
Based on the classification of Darcy Pattison (Vodolazskaya, 2015), the following categories of book trailers created by schoolchildren could be distinguished:

- by content: narrative (focused on the plot): book trailers for the literary works "The Kingdom of Crooked Mirrors", "Cloud Regiment"; atmospheric (conveying the mood and emotions of the reader): book trailer for the series of novels about Harry Potter; and conceptual (translation of the key idea): book trailer for the literary work "The Little Prince";

- by visualization methods: gaming (the book-based minimovie): book trailers for the literary work "The Little Prince", for the series of novels about Harry Potter; nongaming (a set of slides with quotes, illustrations, images, photos, etc.): book trailers for the works "Kingdom of Crooked Mirrors", and "Cloud Regiment".

A group of experts created from the sixth and seventh grades pupils made an expert opinion on each book trailer. The commercial for the literary work of Gubarev "The Kingdom of Crooked Mirrors" was based on the plot of the story and described the fate of the main character. The musical accompaniment and voice-over corresponding to the creative task allowed holding fully the viewer's attention. The authors' own drawings used in the trailer more deeply immersed the viewer in the atmosphere of the story and were of special interest. The authors of the book trailer created an intriguing ending, which made the viewer want to read the advertised work. The disadvantage of the video was the inaccurate transmission of the meaning and idea of the literary text.

The book trailer for the series of books about Harry Potter by Rowling was made in rather dark colors, which conveyed the atmosphere of the fantasy.

Figure 2. Drawings for the book trailer for a series of novels by J.K. Rowling about Harry Potter.

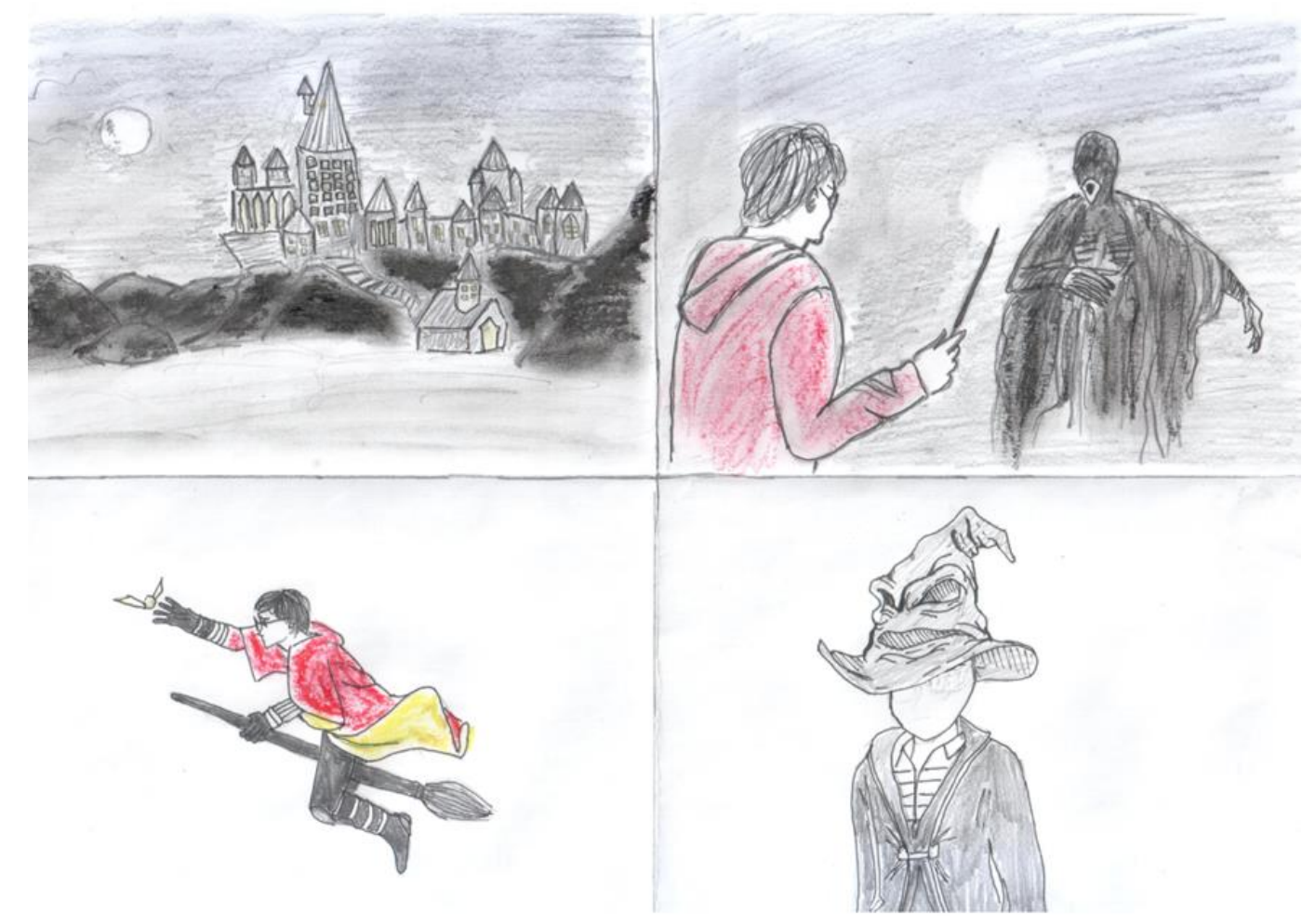

It was aimed at creating a mood in the target audience that corresponded to the peculiarities of the genre and style of the text. Fast change of frames, high-quality animation accompaniment, and accurate selection of actors allowed kindling interest in the viewer. A significant drawback of the book trailer was the lack of voice-over commentary that characterized the plot of the works.

The book trailer for the story of Saint-Exupery's "The Little Prince" was built from quotations from the literary work. This allowed conveying the main idea and mood of the story. High-quality 
sound and voice-over helped to understand the content of what was happening on the screen. Bright shots created an atmosphere of fabulousness. The disadvantage was that the authors did not pay attention to the creativity of such advertising, which should "shock, captivate by the video sequence and unexpected solutions" (Plokhotnik, 2012, p. 21).

The narrative book trailer was created for the story of Verkin's "Cloud Regiment". Correctly using musical accompaniment, photos, text corresponding to the author's idea, the authors conveyed the content and atmosphere of the work about war and children's courage.

Figure 3. Sketches for a book trailer for story of E. Verkin "Cloud Regiment".

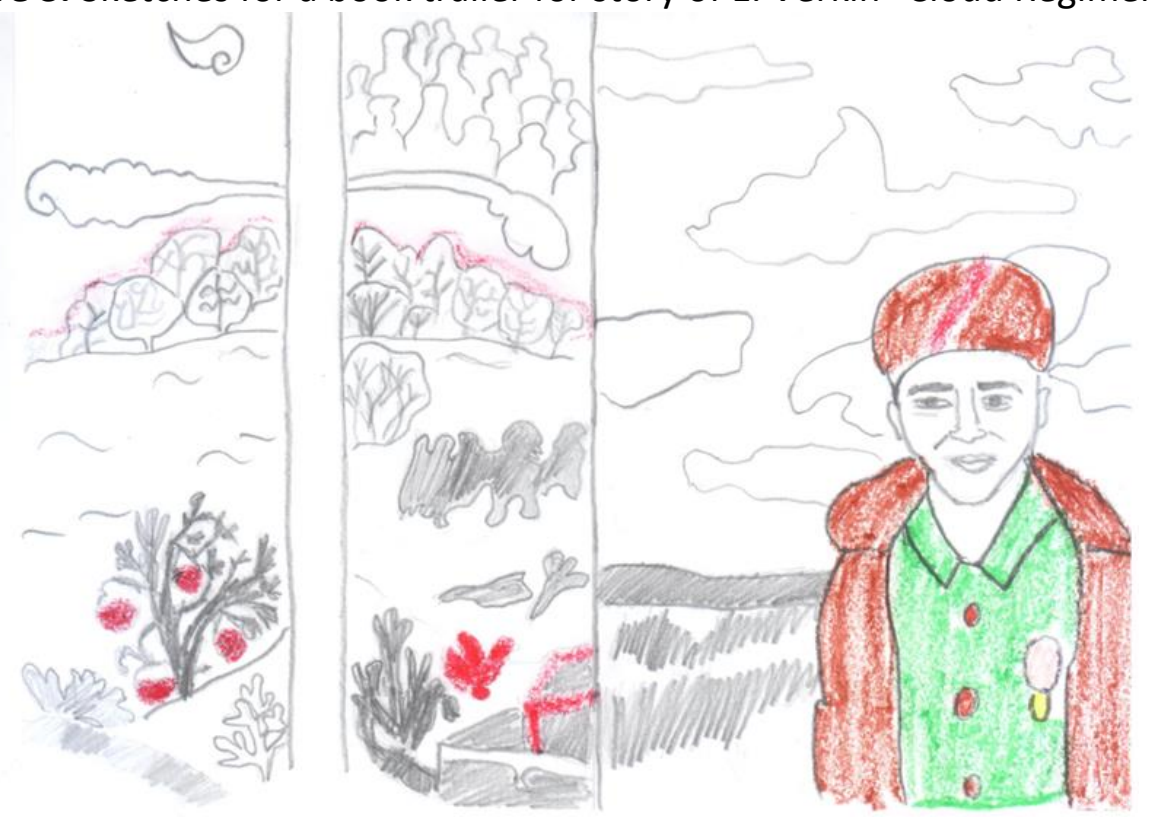

The book trailer introduced the main characters of the story - children, who attracted the attention of schoolchildren. However, experts saw a disadvantage in the fact that the video took a long time - it lasted for 3.5 minutes, so it was difficult for the authors to keep the attention of the reader-viewer on text comments without a voice-over.

The results of approbation of the elective training course "Book Trailer: Create, Watch, and Read" for pupils of the sixth and seven grades of the Second Malzhagar Middle School named after M.E. Vasilyeva of the Republic of Sakha (Yakutia) demonstrate that advertising and communication technology, such as the book trailer, and its creation in the course of learning literature increase the interest of teens to reading, develop creative abilities of pupils, their ability for teamwork, and form the broad competences in various fields of knowledge. The quality of the book trailer as an advertising product allows concluding about the quality of reading and the peculiarities of perception of literary text, about the need to free pupils from the cliches of reader perception, about the importance of interpreting literary texts in the context of the author's position.

\section{DISCUSSION}

After applying the elective training course "Book Trailer: Create, Watch, and Read", a survey was conducted among 47 respondents - pupils of the sixth and seventh grades of the Second Malzhagar Middle School named after M.E. Vasilyeva of the Republic of Sakha (Yakutia).

The survey consisted of the following questions:

1. What book would you read: the one that was shown in the book trailer or the one that was suggested verbally?

2. What affects the effectiveness of the book trailer? 
3. Evaluate on a five-point scale, how effective book trailers are in promoting reading among teenagers.

Absolutely all respondents (100\%) noted that the book trailer was an interesting, contemporary, and productive means of activating reading activity. At that, $80.9 \%$ of respondents expressed a desire to read the literary works advertised by book trailers, $6.4 \%$ of respondents would read the literary works that were advertised orally, and $12.8 \%$ of pupils did not have the desire to read the advertised works.

Answering the second question, the respondents identified the characteristics of book trailers that affected their effectiveness. The answers are shown in table 6.

Table 6. Answers to the question "What affects the effectiveness of the book trailer?».

\begin{tabular}{ll}
\hline The response options & Percentage \\
\hline Content of the advertising text & $20 \%$ \\
Audio support & $18 \%$ \\
Duration & $12 \%$ \\
Visual series & $11 \%$ \\
Video effects & $9 \%$ \\
\hline
\end{tabular}

The majority of respondents gave positive ratings to book trailers as an effective form of promoting reading among teenagers: $68 \%$ rated its effectiveness as excellent, $19 \%$ - as good, and $13 \%$ gave a satisfactory rating.

The results of the study have confirmed that popular communication technology, such as book trailer, can positively influence the interest of schoolchildren in book reading in the course of the education, enhance the reading activity of adolescents, improve their skills in analyzing literary texts and creative abilities, and form information, communication, and reading competencies. A significant outcome of the study is a website for schoolchildren and teachers entitled "Book trailers of Yakutia" (www.btrailers.ru), created by one of the participants of the experiment - a rural teacher of the Russian language and literature. The site was launched in March of 2020 to promote book trailers as a contemporary form of communication, to actively promote books and reading. The website is an important tool for promoting books and reading on social networks (Tabernero-Sala \& Calvo, 2019), it contains information about book trailers useful for the educational community: this includes history, definition, characteristics and features, commercials of books created by pupils of schools and librarians of the Republic of Sakha (Yakutia), as well as the instructions for creating own book trailers.

\section{CONCLUSION}

The observation conducted for six months of 2020 has shown that rural school adolescents, involved in the study, began to devote more time to reading literary works, their interest in classical and contemporary literature increased, and the reading became more selective.

Practical implementation of learning tool relevant for modern school allows concluding that independent creation of book trailers contributed to the development of critical thinking, cognitive and research abilities of pupils, skills of working with various software applications and devices.

Creating book trailers in literature lessons develops creative abilities, imaginative and critical thinking of schoolchildren, forms the need for meaningful reading of literary works, and develops teamwork skills. Viewing book trailers increases interest in the book and reading in general, as well as teaches to critically perceive incoming information.

The popularity of book trailers as a source of information that does not require for timeconsuming and special intellectual efforts, is only growing. They are able to act as a "cultural unit" 
(Vollans, 2016), as an important socio-cultural phenomenon that shapes fashion in the youth reading environment.

However, the life cycle of this video format is, probably, coming to an end. It will be replaced by new technologies for broadcasting ideas, meanings, and personal stories in the near future. Perhaps tomorrow the generation of trailer lovers will be replaced by the generation of lovers of holograms or other technological innovations. Schoolchildren will have to master new technologies for creating an information product. At the same time, one thing remains unchanged - the latest technologies in the process of literary education should serve as an efficient tool for learning culture, art, literature, designed to enrich the inner world of a person, to develop spiritually rich personality.

Acknowledgments: The article was prepared in the framework of the grant of the Ministry of Education of the Russian Federation in the form of subsidies for the implementation of events aimed at proper functioning and developing the Russian language, the departmental target program "Scientific and methodological, methodological and staffing support of teaching the Russian language and the languages of the peoples of the Russian Federation", subprogram "Improving the education system management" of the state program of the Russian Federation "Development of education" (Agreement No. 073-15-2020-2637).

\section{REFERENCES}

Aliagas-Marín, C., Margallo, A.M. (2016). Digital storytelling, book trailers and literary competence in initial teacher education (Book Chapter). Storytelling and Education in the Digital Age: Experiences and Criticisms.

Araujo, A., \& Silva, I. P. (2020). Maker culture and educational robotics in physics teaching: developing an automated traffic light in high school. Journal of Research and Knowledge Spreading, 1(1), e11654.

Astafyev, V.P. (2008). Zatesi [Zatesi]. Moscow: Eksmo.

Baize, J. (2019). Classics in their own «Words»: Analytical remixes in a land of essays. Journal of Adolescent and Adult Literacy, 62(6), 625-633.

Basaraba, N. (2016). Creating Persuasive Book Trailers as a New Media Marketing Tool. Logos-Journal of the World Publishing Community, 3, 34-51.

Brössel, S. (2018). Buchtrailer. Ein audiovisuelles Kleinformat an der «Schnittstelle» zwischen Buch und Film Kodikas. Code, 41(1), 30-51.

Bulanova-Toporkova, M.V. (2006). Pedagogicheskie tekhnologii: uchebnoe posobie [Pedagogical technologies: A textbook]. Rostov-on-Don.

Dimova, M., Slavova-Petkova, S., and Luchev, D. (2018). Models of digital book trailers and applications of digital storytelling approach for educational purposes. Digital Presentation and Preservation of Cultural and Scientific Heritage, 8, pp. 197-206.

Federal'nyj gosudarstvennyj obrazovatel'nyj standart osnovnogo obshchego obrazovaniya [Federal State Educational Standard of Basic General Education]. Retrieved from: https://fgos.ru

Ibarra-Rius, N., Ballester-Roca, J. (2018). Digital storytelling in teacher training: Development of basic competencies, creativity, and multimodal literacy through book trailers (Book Chapter). Teaching Language and Teaching Literature in Virtual Environments, pp. 241-254.

Kak sdelat' buktrejler? [How to make a book trailer?]. Literary club "Your first book" Retrieved from: https://tvoya1kniga.ru/kak-sdelat-buktreyler\#more-1074

Kolova, S.D., Vrublevsky, A.S. (2019). Obrazovatel'nye i pedagogicheskie vozmozhnosti tekhnologii buktrejlera v literaturnom obrazovanii shkol'nikov [Educational and pedagogical opportunities of book trailer technology in literary education of schoolchildren]. Issues of Theory and Practice, 3, 462-465.

Kopylova, V. (2012). Chto takoe buktrejler? Rossiya na poroge novoj knizhnoj ery [What is a book trailer? Russia on the threshold of a new book era]. Arguments and Facts. Retrieved from: http://www.aif.ru/culture/38268\#

Mokhun, O.A. (2016). Buktrejler kak innovacionnoe sredstvo povysheniya interesa chteniya u shkol'nikov [Book trailer as an innovative means of increasing the interest of reading among schoolchildren]. Proceedings of the $3^{\text {rd }}$ All-Russian scientific and methodological Conference "Teaching Russian language and literature: Forms, methods, and innovations". 
Morozov, V.F., Lisovskaya, T.A. (2014). Buktrejler - sovremennyj sposob prodvizheniya knigi v biblioteke: metodicheskie rekomendacii [Book trailer: A modern way to promote books in the library: guidelines]. Petrozavodsk: Morozov Children and Youth Library of the Republic of Karelia.

Oliveira, A. M., Gerevini, A. M., \& Strohschoen, A. A. G. (2017). Diário de bordo: uma ferramenta metodológica para o desenvolvimento da alfabetização científica. Revista Tempos e Espaços em Educação, 10(22), 119-132.

Plokhotnik, T.M. (2012). Novoe blyudo bibliotechnoj kuhni. Buktrejler podan [A new dish of library cuisine: Book trailer is served]. Librarianship, 6, 20-22.

Rodrigues, B. M., Santos, J. E. B., \& Vasconcelos, C. A. (2020). Conceptions of undergraduate students in Chemistry on the use of interactive interfaces in and for the activities developed in the distance course. Journal of Research and Knowledge Spreading, 1(1), e11649.

Romero Oliva, M.F., Ponce, H.H., Hernández, M.S. (2019). The book trailer as a digital tool in the training literary reading of future teachers: a case study. Caracteres, 8(2), 92-28.

Santos, J. E. B. (2020). Cartographic narratives: the teaching of mathematics and ICT. Journal of Research and Knowledge Spreading, 1(1), e11645.

Shcherbinina, Yu.V. (2016). Buktrejlery v shkol'noj praktike prepodavaniya literatury [Book trailers in the school practice of teaching literature]. Proceedings of the $8^{\text {th }}$ International science-to-practice conference "Pedagogy of text". Saint-Petersburg, LEMA Publishing House.

Tabernero-Sala, R. (2016). Public online epitexts to children book promotion. Towards a book-trailer poetic. A model analysis. Ocnos-Revista de Estudios sobre la Lectura, 2, 21-36.

Tabernero-Sala, R., Calvo, V. (2019). Virtual epitexts in the dissemination of children's books: Toward an analytical model for author websites. Zeitschrift fur Katalanistik, 32, 65-87.

Ulitskaya, L.E. (2012). Detstvo sorok devyat' (sbornik). [Childhood forty-nine (collection)]. Moscow: Astrel.

Vodolazskaya, S. (2015). Buktrejler kak sposob vizual'noj kommunikacii cherez videohostingi [Book trailer as a way of visual communication through video hosting]. Innovations in Science, 46, 75-79.

Volkova, N.V. (2015). Buktrejler kak «vizual'noe esse» v kontekste formirovaniya chitatel'skogo interesa [Book trailer as a "visual essay" in the context of the formation of readers' interest]. Culture. Spirituality. Society, 16, $209-223$.

Vollans, E. (2016). Think of It as a Trailer ... for a Book. Publications, 4, 32.

Yakina, L.N. (2014). Buktrejler - kul'turnoe yavlenie? [Book trailer: Is this a cultural phenomenon?]. Man in the World of Culture, 1, 42-45.

Zalutskaya, S.Yu., Nikonova, N.I. (2020). Professional'naya podgotovka budushchih uchitelej russkogo yazyka i literatury: tekhnologiya reklamirovaniya i chitatel'skie interesy obuchayushchihsya [Professional training of future teachers of the Russian language and literature: Advertising technology and reader interests of learners]. Prospects of Science and Education, 3(45), 114-125.

Received: 11 January 2021 | Accepted: 6 February 2021 | Published: 16 February 2021 